\title{
A tribute to Philippe Clerc: an eminent and multitalented lichenologist in Switzerland
}

\author{
Alice Gerlach ${ }^{1 *}$, Daniel Rodrigues ${ }^{1}$, Juan Manuel Rodriguez ${ }^{2}$, Carlos Rojas ${ }^{3}$, Stella Temu ${ }^{4,5}$ \\ \& Gintaras Kantvilas ${ }^{6}$
}

Philippe Clerc was born on April 26, 1955, in Lausanne, Switzerland. He was as an undergraduate at the University of Geneva when he stumbled upon an article in the newspaper Tribune of Geneva about lichens and air pollution that first sparked his interest in lichens. To learn more, he went to Professor G. Turian, who was cited in the article and who loaned him a few books and a microscope, saying 'First you have to know the species'. So a lichen taxonomist was born! His first academic work dealt with the application of lichens as bioindicators of air pollution in the Wallis region of Switzerland (Clerc \& Roh 1979a, b). He obtained his master's degree in Biology under Prof. Turian's supervision in 1979.

Philippe found his career path through the opportunity to work as a research assistant in the Department of Cryptogamy at the University of Bern under Prof. Klaus Ammann. The Eduard Frey (1888-1974) lichen collection had been acquired recently by the University and, in this collection, Philippe started to study the genus Usnea (the popular 'old man's beard' lichen), which would become his main scientific interest for the next four decades. His first step was to visit Lublin (Poland) to study the collection of the Polish botanist and lichenologist, Józef Motyka (1900-1984), who had published a world monograph of the genus (Motyka 1936-38). The taxonomy and classification of Usnea appeared chaotic at that time and the genus was renowned as one of the most difficult to identify to species level due to its wide phenotypic plasticity and seeming over-abundance of names (as many as 1243). As Philippe later reflected: 'the first two years of my thesis were completely in the shadows', but he persisted and

\footnotetext{
${ }^{1}$ Conservatoire et Jardin botaniques de la Ville de Genève, 1 ch. de l'Impératrice, 1292 Chambésy/GE, Switzerland

${ }^{2}$ Instituto de Investigaciones Biológicas y Tecnológicas IIBYT, Córdoba, Argentina

${ }^{3}$ Instituto de Investigaciones en Ingeniería, Universidad de Costa Rica, San Pedro de Montes de Oca, 11501, Costa Rica

${ }^{4}$ Dept. of Molecular Biology and Biotechnology, University of Dar es Salaam (UDSM), Tanzania

${ }^{5}$ Dept. of Organismal Biology, Uppsala University, Sweden

${ }^{6}$ Tasmanian Herbarium, Tasmanian Museum \& Art Gallery, PO Box 5058, UTAS LPO, Sandy Bay, Tasmania 7005, Australia

* Corresponding author e-mail: alice gerlach@yahoo.com.br
}

gradually dismantled and refined the taxonomy of Usnea. His first publications about the genus were soon published (Clerc 1984a, b) and, at the same time, he also obtained his secondary education certificate (Biology section, under Prof. M. Villard). He was awarded his PhD - 'Taxonomy and systematics of the genus Usnea in Europe - Preliminary studies towards a monograph' - in 1986 under the supervision of Professor K. Ammann.

After acquiring his doctorate, he moved with his family to the USA to take up a Postdoctoral Research Fellowship at Duke University (North Carolina, USA) under Professors William L. Culberson and Rytas Vilgalys. This was an opportunity to study molecular biology and he became a pioneer in the molecular systematics of Parmeliaceae (1990-1993). He spent 15 months there (1988-1989).

Returning to Bern, he started his career, funded by a National Foundation Research Fellowship, which enabled him to continue his project on the molecular systematics of the Parmeliaceae s.l. (lichenized Ascomycetes) that he began during his tenure as a post-doctoral researcher. The molecular era in the classification of lichens was just beginning, and this enabled the elucidation of the biological nature of lichen chimeras (or photosymbiodemes). It was established that the mycobiont in a chimera is only one species (not two as previously believed) and that the different vegetative morphology is determined by the associated photobiont (Armaleo \& Clerc 1991, 1995) (Fig. 2B).

He moved with his grant to Geneva in 1991 and, with Jean-François Manen (Geneva University), helped to establish the first molecular laboratory at the Conservatoire et Jardin botaniques de Genève.

In 1993, Philippe was appointed to curator position at Conservatoire et Jardin botaniques in the City of Geneva (CJBG), at that time directed by Rodolphe Spichiger, where he has remained for the remainder of his working life. Geneva had a strong lichen tradition and one of the world's most important lichen herbaria, thanks to the efforts of Johannes Müller (known as Müller Argoviensis), one of the most influential lichenologists of the 19th century. Müller had been a greatly respected Professor of Botany at the University of Geneva for 18 years and the 
Director of the Botanical Garden of Geneva for four years. After him, there was a gap of 98 years before Philippe was appointed as lichenologist. Lichenology had returned to the heart of Europe!

Philippe devoted his entire professional career to the study of the genus Usnea. He published on the species concept in the genus (Clerc 1998), where the most important phenotypical characters were identified and discussed, and so laid the foundation for his subsequent studies, as well as those of others. He revised Motyka's monograph that had been the key publication on Usnea for decades. His enormous contribution to Usnea taxonomy is underlined by his great number of publications, including book chapters (Table 1), new records and species (Table 2), and notes about the genus, plus illustrations, keys to identifications and a checklist with information on all of the Usnea types worldwide (Clerc et al., unpubl.) (Fig. 1). He is rightly regarded as the worldwide expert on the genus.

Philippe is a true field lichenologist and believes that systematics should begin by studying as many specimens

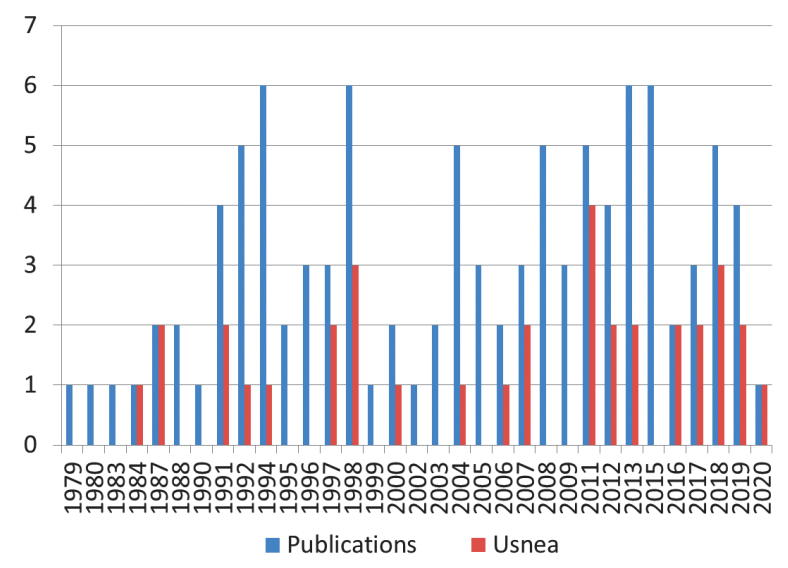

Figure 1. Philippe Clerc's publication timeline. Highlighted in red are the publications focusing on the Systematics of the genus Usnea. From Recent Literature of Lichens.

as possible, both in the field and in the herbarium. He would take copious ecological notes in the field. His many expeditions to collect and study lichens were mainly in Europe (the British Isles, France, Norway, Russia), but also included the Macaronesian region, Zimbabwe, North America (New Jersey, etc.), the Galapagos, Costa Rica, El Salvador, Brazil, Chile and Australia (Fig. 2). With respect to the diversity of Usnea, Philippe believed that Brazil or, more specifically, the southern São Joaquim National Park, was the most species-rich territory in the world.

Today there are only some three other lichenologists in Switzerland, all working mainly on lichen conservation, the Red List and inventories: Mathias Vust, Silvia Stofer and Christoph Scheidegger, all in Zurich (Vust 2019, pers. comm.). Philippe is thus the rare lichen taxonomist in this small country in the heart of Europe. However, he has also contributed to other topics in his active life as a researcher (Fig. 3), including: lichen conservation in Switzerland and the red-list (e.g., Vust et al. 2015), lichen inventory (e.g., Habashi \& Clerc 2012, 2013a, b), chemistry (e.g., Gadea et al. 2019), molecular biology (Armaleo \& Clerc 1991, 1995; Clerc et al. 1991; Döring et al. 2000; Truong et al. 2013; Divakar et al. 2015; Gerlach et al. 2018; Temu et al. 2019; Jung et al. 2019), the taxonomy in genera other than Usnea (e.g., Botryolepraria Canals et al., Candelariella Müll. Arg., Melanohalea O. Blanco et al., Melaspilea Nyl., Menegazzia A. Massal., Parmelia Ach., Parmelina Elix \& Hale, Rinodina (Ach.) Gray, Tetramelas Norman, Verrucaria Schrad., Waynea Moberg, and many regional lichen inventories (e.g., for Alaska, Canary Islands, France, Italy, Scandinavia, Switzerland). In recognition of his work identifying African lichens, Pertusaria clercii Messuti \& A.W. Archer was described (Messuti et al. 2007). More recently, Aspicilia clercii Cl. Roux \& M. Bertrand, another saxicolous crustose species, was described in recognition of his invaluable taxonomical studies on lichens from the Alps (Nimis et al. 2018; Roux 2020). Philippe has also published many outreach articles (see below) and even collaborated on a publication reporting the first myxomycetes (slime molds) of El Salvador (Rojas et al. 2013). A complete list of his scientific publications can be seen at the Recent Literature on Lichens webpage (http://nhm2.uio.no/botanisk/ lav/RLL/RLL.HTM).

Philippe has always been deeply involved in the herbarium and was appointed head curator of the botanical collections at the CJBG in 2008. He is passionate about classification and dedicated much time to identifying and classifying the lichen herbarium, locating and cataloguing the type specimens (with the help of his collaborator, Matthieu MacGillycuddy), and bringing the classification of the collection into line with modern concepts with the help of molecular tools. He also actively participated in the acquisition and incorporation of many satellite fungal herbaria, among them Paul Ozenda's lichen collection (2002 and 2010, 5,500 specimens), Pierre Neuville's Basidiomycete collection (2012, 6,000 specimens), François Ayer's fungal collection (2012, 6,800 specimens), Jean Bozonnet's myxomycete collection (2013, 4,000 specimens), Mathias Vust's lichen collection of the Red List of the Geneva Canton, (2014, 1,700 specimens), Marianne Meyer's collection of Myxomycetes (2016-2017, 40,000

Table 1. Usnea chapters published by Philippe Clerc in general books about lichens.

\begin{tabular}{l|l}
\hline Books Lichen Biota & \multicolumn{1}{c}{ Editors and year } \\
\hline $\begin{array}{l}\text { Nordic Lichen Flora } \\
\text { Lichen Flora of the Greater Sonoran Desert Region } \\
\text { The lichens of Great Britain and Ireland }\end{array}$ & A. Thell \& R. Moberg (eds). 2011 \\
Nie Flechten & Purvis, O.W.; B.J.Coppins, D.L. Hawksworth, P.W. James \& D.M. Moore (eds). 1992 \\
Cryptogamica Helvetica & Wirth, V.; M. Hauck \& M. Schult (eds). 2013 \\
\hline
\end{tabular}



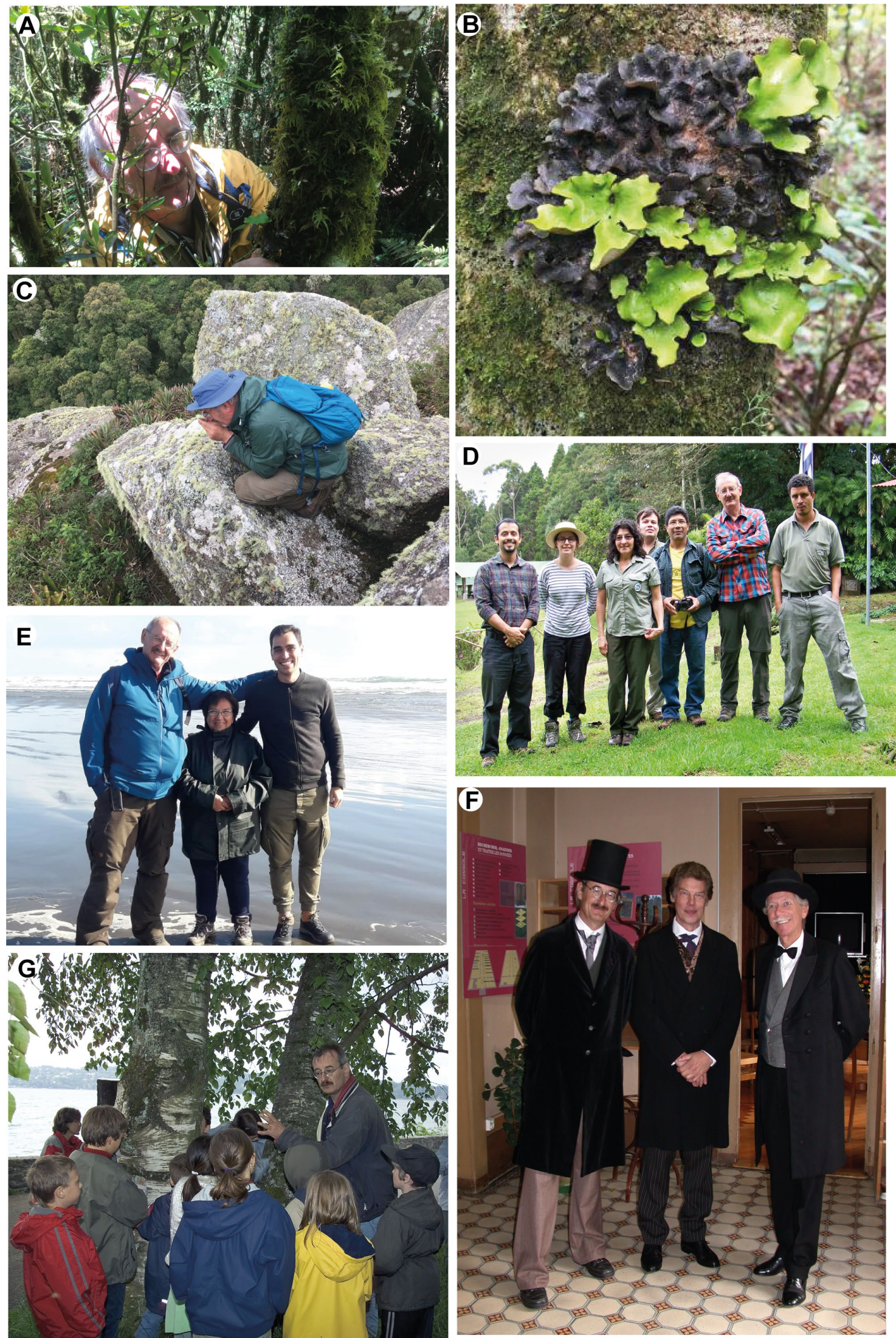

Figure 2. A - Philippe in the field at Santa Catarina State, São Joaquim National Park (Brazil, 2017) observing and collecting a photosymbiodeme lichen [photo by Alice Gerlach]; B - the lichen photosymbiodeme collected by Philippe at the same locality [photo by Alice Gerlach]; C - Philippe examining saxicolous Usnea in Minas Gerais State, Pedra Bonita (Brazil 2017) [photo by Alice Gerlach]; D - Philippe during an expedition in September 2014 to the Grecia Forest Reserve, Costa Rica. From left to right: Carlos Rojas (from University of Costa Rica), Gabriela Loza, a park ranger, Randall Valverde (from University of Costa Rica), Ricardo Morales (from University of El Salvador), Philippe and another park ranger; E - Philippe with Iris Pereira (Talca University, Chile) and his student Daniel Nunes during an expedition to Ilê de Chiloé, Chile, in March 2019 to recollect Usnea flavocardia; F - Philippe with Fernand Jacquemoud and Marc-André Thiébaud for the 100 birthday of the Console [photo by Bernard Renaud]; G - Philippe during an outreach atelier (Atelier vert) showing lichens to children at Geneva Botanical Garden. 
Table 2. List of taxa published by Philippe Clerc.

\begin{tabular}{l}
\hline New combinations \\
\hline Diplotomma hedinii (H. Magn.) P. Clerc \& Cl. Roux \\
Lichinella heppii (Müll. Arg.) P. Clerc \& Cl. Roux \\
Parmelina atricha (Nyl.) P. Clerc \\
Porpidia turgida (Ach.) Cl. Roux \& P. Clerc \\
Tetramelas thiopolizus (Nyl.) Giralt \& P. Clerc \\
Usnea cirrosa subsp. ramillosa (Motyka) P. Clerc \\
Usnea cornuta subsp. brasiliensis (Zahlbr.) P. Clerc \\
Usnea fragilescens var. mollis (Vain.) P. Clerc \\
Usnea hirta subsp. trachista (Motyka) P. Clerc \\
Usnea praetervisa (Asahina) P. Clerc \\
Usnea subfloridana subsp. praetervisa (Asahina) P. Clerc \\
Waynea stoechadiana (Abassi Maaf \& Cl. Roux) Cl. Roux \\
\& P. Clerc
\end{tabular}

New species

Rinodina canariensis Matzer, H. Mayrhofer \& P. Clerc

Usnea ammannii P. Clerc \& Herrera-Camp.

Usnea aranea Truong \& P. Clerc

Usnea arianae P. Clerc, E. Caviró \& A. Gerlach ad int.

Usnea aurantiaciparvula A.Gerlach \& P. Clerc

Usnea boomiana P. Clerc

Usnea brattiae P. Clerc

Usnea cedrosiana P. Clerc

Usnea crenulata Truong \& P. Clerc

Usnea crocata Truong \& P. Clerc

Usnea cylindrica P. Clerc

Usnea esperantiana P. Clerc

Usnea exigua J.M. Rodriguez \& P. Clerc

Usnea flabelliformis A. Gerlach \& P. Clerc ad int.

Usnea flavorubescens Truong \& P. Clerc

Usnea fleigiae A. Gerlach \& P. Clerc

Usnea galapagona Truong \& P. Clerc

Usnea geissleriana P. Clerc

Usnea grandisora Truong \& P. Clerc

Usnea grandispora A. Gerlach \& P. Clerc

Usnea halei P. Clerc

Usnea kalbiana P. Clerc \& A. Gerlach

Usnea krogiana P. Clerc

Usnea lutii J.M. Rodr. \& P. Clerc

Usnea macaronesica P. Clerc

Usnea mayrhoferi Herrera-Camp., Bungartz, Truong

\& P. Clerc

Usnea myrmaiacaina P. Clerc

Usnea nashii P. Clerc \& Herrera-Camp.

Usnea oreophila A. Gerlach \& P. Clerc

Usnea patriciana Bungartz, Herrera-Camp. \& P. Clerc

Usnea rubricornuta Truong \& P. Clerc

Usnea rubriglabrata Truong \& P. Clerc

Usnea rubropallens A. Gerlach \& P. Clerc ad int.

Usnea sanctaeritae P. Clerc \& Herrera-Camp.

Usnea saxidilatata J.M. Rodr. \& P. Clerc

Usnea stipitata A. Gerlach \& P. Clerc ad int.

Usnea subaranea Truong \& P. Clerc

Usnea subcomplecta Truong, P. Clerc \& Herrera-Camp.

Usnea subdasaea Truong \& P. Clerc

Usnea subflammea P. Clerc

Usnea subflaveola Truong \& P. Clerc

Usnea subglabrata Truong \& P. Clerc

Usnea subparvula A. Gerlach \& P. Clerc

Usnea subrubicunda P. Clerc

Usnea tenuicorticata P. Clerc \& A. Gerlach ad int.

Usnea viktoriana $\mathrm{P}$. Clerc \& Otte

Usnea vitrea P. Clerc \& Herrera-Camp.

Usnea wirthii P. Clerc

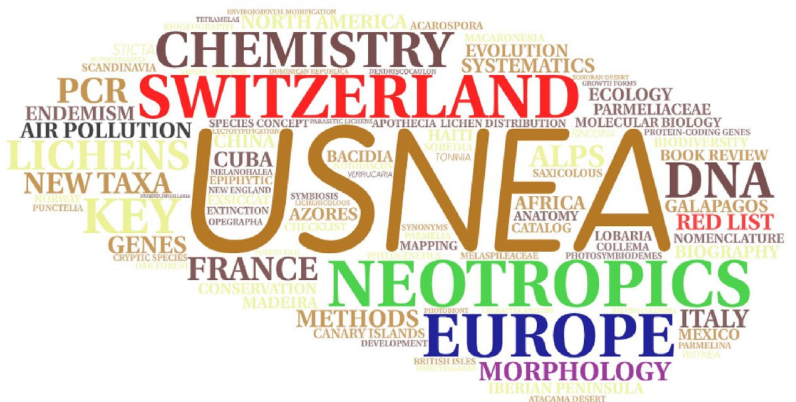

Figure 3. Word cloud based on the keywords from Philippe's publications.

specimens), and the Coire herbarium collection (2006 and 2017, 4,700 specimens). These acquisitions greatly increased the scope and significance of the Geneva Cryptogamic herbarium $(\mathrm{G})$, making it an invaluable resource for mycologists worldwide. Philippe leaves a herbarium that is almost up to date with current taxonomy.

During his work, Philippe organized several guided visits for the general public to the CJBG to show the diverse biological aspects of the lichen symbiosis. He contributed his scientific expertise to the organization of the Murs sanctuaires - A la découverte des murs de la Ville de Genève (which can be downloaded here: https:// patrimoine-vert-geneve.ch/murs-sanctuaires-de-la-villede-geneve) and organized a lichen exhibition at Mycorama (Neuchatel, Switzerland, 2008), which featured many informative banners, a wonderful glass cabinet full of colored lichens, big rocks covered in crustose lichens, and a model of an apothecium to illustrate sexual reproduction in lichens. He was always enthusiastic to show off to the public his place of work, the Conservatoire botanique ('maybe a place where musicians are playing while looking at the plants', he joked), including La Console, where the cryptogam herbarium, library, molecular laboratory and many offices are housed. Philippe also organized or collaborated in events such as La nuit de la science (The night of science), les Ateliers verts (outreach ateliers for children), and exhibitions.

Philippe was appointed Lecturer at the University of Geneva, Faculty of Sciences in 2000, where he and Michelle Price were responsible for teaching 'Systematics and ecology of lichens and bryophytes'. He organized a workshop on the Physciaceae in the Geneva Botanical Garden (Clerc 2009) and was invited to give an Usnea workshop in Sweden in 2011. His passion for nature, and his ability to explain science with precision, but in an easily understandable way, was frequently show-cased by the Swiss media.

Philippe has been a valued and influential mentor to his Masters and Doctoral students, always very generous and supportive, while giving them the freedom to develop their scientific independence. He successfully mentored many students in taxonomy and ecology from South America, Europe and Africa, a number of whom have become well established and forged their own careers in lichenology or mycology, including Marusa Herrera-Campos (PhD, 1997), Pekka Halonen (PhD, 2000), Mathias Vust (PhD, 2001), Juan Manuel Rodriguez (PhD, 2011), 

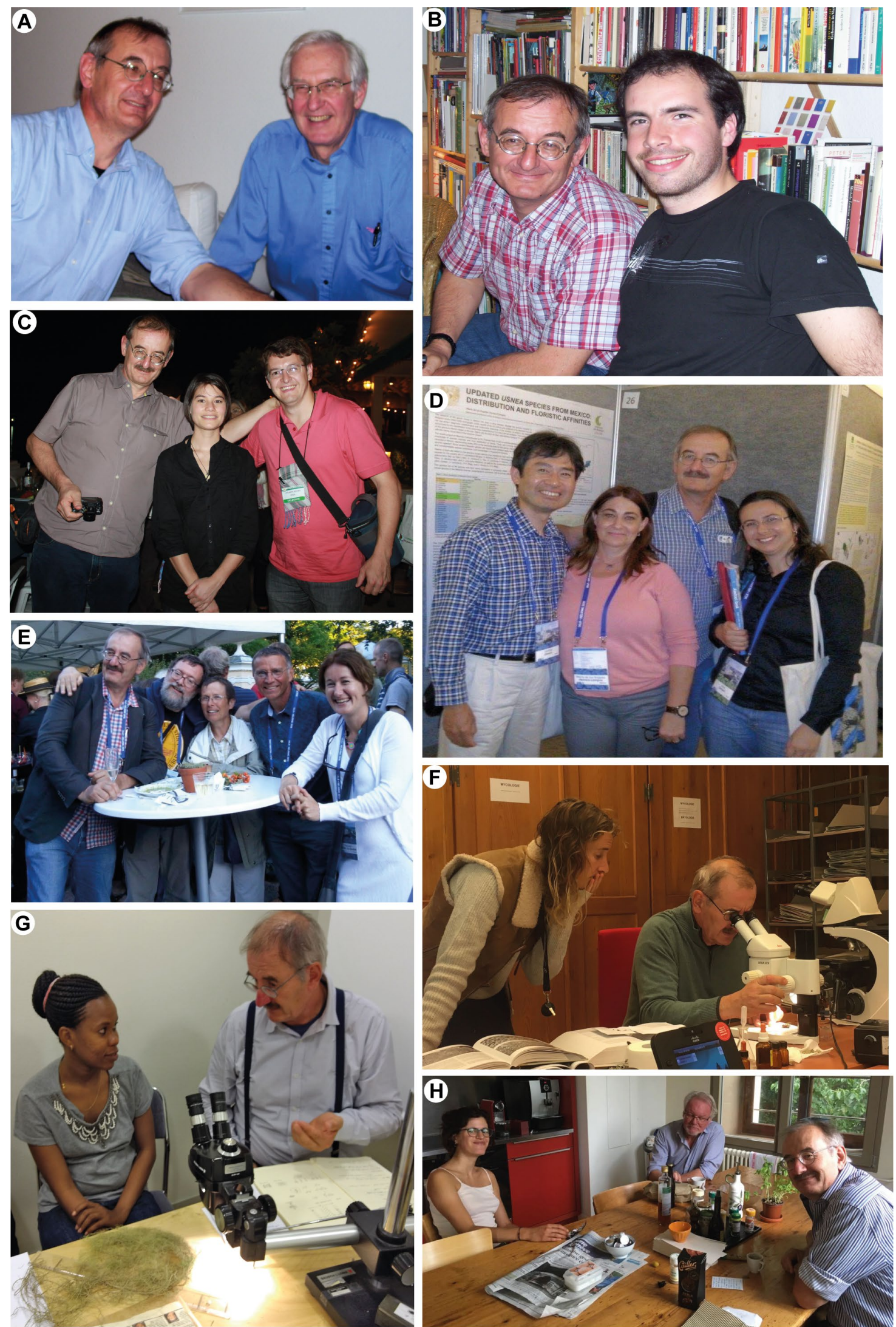

Figure 4. A - Philippe with Roland Moberg during the Physciaceae workshop at CJBG in 2008 [photo by Juan Manuel Rodriguez]; B - Philippe with his student Juan Manuel Rodriguez at Geneva in November 2008; C - Philippe with Adriano Spielmann and his student Camille Truong during the IAL-7 symposium, Thailand 2012 [photo by Luciana Cañez]; D - Philippe with his student Alice Gerlach and collaborators, Yoshihito Ohmura and Marusa Herrera Campos, during the IAL-8 symposium, Finland 2016; E - Philippe with the French lichenologist team during the IAL-8 symposium, Finland 2016: Joel Esnault (AFL), Michel Bertrand's wife, Michel Bertrand (AFL) and Françoise Lohezic-Le Devehat (Rennes University) [photo by Alice Gerlach]; F - Philippe with his student Anne Kissling at CJBG in 2017 [photo by Alice Gerlach]; G - Philippe introducing his $\mathrm{PhD}$ student, Stella Temu, to Usnea taxonomy during his visit to the Evolutionary Biology Centre, Uppsala University, Sweden on October 10, 2017. [photo by Sanja Tibell]; H - Philippe with his student Maud Oïhénart and collaborator Othmar Breuss (Verrucariaceae experts) at CJBG in 2017 [photo by Alice Gerlach]. 
Camille Truong (PhD, 2012), who also described Usnea clerciana Truong in his honor, Alice Gerlach (PhD, 2017), Maud Ö̈hénart (Master, 2018), Anne Kissling (Master, 2019), Daniel Nunes (Master, 2020), and Stella Temu ( $\mathrm{PhD}$ in progress). All have been deeply instilled with Philippe's passion for his subject and his adherence to accuracy and good science. They and all of his colleagues in Switzerland, Europe and far beyond, wish him well for the future (Fig. 4).

\section{Some outreach publications by Philippe Clerc}

Clerc, P., Manen, J-F., Savolainen, V. 1991. Les nouvelles techniques au service de la taxonomie et de l'étude de la végetation. L'emploi de techniques de biologie moléculaire en systématique. Feuille Verte 20: 6-7.

Clerc, P., Camenzind, R., Dietrich, M., Groner, U., Grundlehner, S., Oberli, F., Scheidegger, C. \& Wildi, E. 1992. Lobaria amplissima (Scop.) Forss. dans les Prealpes Vaudoises. Meylania 1: 16-20.

Clerc, P. 1993. Quelques réflexions sur le congrès de lichenologie (IAL 2) qui s'est tenu a Lund (S), du 30 août au 4 septembre 1992. Meylania 3: 7-8.

Clerc, P. 1994. Les races chimiques chez les lichens doiventelles être considérées comme des espèces ou non? Une vieille dispute, maintenant désuète! Meylania 6: 21-23.

Fiore, A.-M. \& Clerc, P. 1996. Collema coccophorum: une nouvelle espèce pour la Suisse. Meylania 11: 14-16.

Clerc, P. 1998. Les années 80-90, une période faste pour la lichénologie suisse. Meylania 14: 14-19.

Vust, M. \& Clerc, P. 1998. Inventaire de la flore lichénique terricole de Suisse. Meylania 14: 27-29.

Clerc, P. 1998. Usnea cornuta et Fellhaneropsis myrtillicola: deux espèces nouvelles ou peu connues d'ascomycètes lichénisés en Suisse. Meylania 15: 23-26.

Clerc, P. 2004. Menegazzia subsimilis (Ascomycète lichénisé) nouveau pour la Suisse, la Chine, la Scandinavie (Norvège), la France et la côte est des Etats-Unis. Meylania 29: 11-19.

Clerc, P. 2005. Premiers compléments au Catalogue des lichens de Suisse. Meylania 31: 8-12.

Clerc, P. \& Dietrich, M. 2005. Botryolepraria lesdainii (Hue) Canals et al. nouveau pour la Suisse. Meylania 34: 11-15.

Clerc, P. 2006. Parmelia afrorevoluta et P. britannica: deux nouvelles espèces de macrolichens pour la Suisse: une redéfinition de Parmelia revoluta! Meylania 35: 7-15.

Clerc, P. 2006a. Editorial. Saussurea 36: 5.

Clerc, P. 2006b. Un travail de détective. Hotspot 13: 8.

Gautier, L. \& Clerc, P. 2006c. L'African Plants Initiative. La feuille verte 37: 12 .

Gautier, L., Jacquemoud, F. \& Clerc, P. 2008a. Un nouvel écrin pour nos herbiers. La feuille verte 39: 11.

Clerc, P. \& Truong, C. 2008b. Une flore du 21e siècle: La flore numérique des lichens de Suisse. La feuille verte 39: 14-15.

Clerc, P. \& Truong, C. 2008c. Les CJB présentent une exposition permanente sur les lichens au Mycorama. La feuille verte 39: 13.

Clerc, P. \& Truong, C. 2008d. Un projet de Flora numérique de suisse (FNLS). Meylania 40: 20-28.
Clerc, P. \& Beauchamps, H. 2008. Verrucaria bryoctona (Th. Fr.) Orange, une nouvelle espèce de lichens pour la Suisse. Meylania 41: 7-10.

Clerc, P. 2009. Un cours sur les Physciaceae aux Conservatoire et jardin botaniques de la Ville de Genève. Meylania 42: $36-37$.

Clerc, P. 2009. Deuxième complément au Catalogue des lichens de Suisse. Meylania 42: 7-14.

Clerc, P. \& Palese, R. 2010. Le catalogue des lichens de Suisse est maintenant sur le web. La feuille verte 41: 9.

Clerc, P. 2011. La Ville de Genève remporte le concours du mur urbain le plus riche en espèces de Suisse. La feuille verte 42: 12 .

Clerc, P. 2011. Les CJB participent à la flore des lichens des pays nordiques. La feuille verte 42: 13.

Price, M. \& Clerc, P. 2011. Les CJB publient une révision mondiale du genre Grimmia (bryophytes). La feuille verte 42: $12-13$.

Clerc, P. 2011. Les tâches multiples d'un(e) employée(e) d'herbier en Cryptogamie aux CJB. La feuille verte 42: 24.

Gautier, L., Clerc, P. \& Fischer-Huelin, D. 2011. Les établissements publics pour l'intégration (EPI) collaborent au fonctionnement du secteur Herbier des CJB. La feuille verte 42: 23.

Clerc, P. 2011. Les Conservatoire et jardin botaniques au Festival Salamandre à Beausobre (Morges). La feuille verte 42: 26 .

Clerc, P. 2012. Déménagement des collections de la Console. La feuille verte 43: 18.

Clerc, P. 2012. Vers une «Nouvelle Console». La feuille verte 43: 19 .

Haluwyn, C. Van, Asta, J., Boissiere, J.-C. \& Clerc, P. 2012. Guide des lichens de France: lichens des sols. L'Indispensable guide des... Fous de nature [Paris], Belin. 223.

\section{Acknowledgements}

The first author acknowledges her colleagues from the Conservatoire et Jardin botaniques of the City of Geneva (CJBG) for discussions and photos taken during Philippe's career, especially Anne Kissling, Christine Habashi, Daniel Jeanmonod, Isabella Valette, Magali Stitelmann, Matthieu MacGillycuddy and Yamama Naciri. We also acknowledge Mathias Vust for providing some outreach publications written by Philippe Clerc. Thanks to all of the contributors to this special volume for their efforts in contributing scientific papers.

\section{References}

Armaleo, D. \& Clerc, P. 1991. Lichen chimeras: DNA analysis suggests that one fungus forms two morphotypes. Experimental Mycology 15: $1-10$.

Armaleo, D. \& Clerc, P. 1995. A rapid and inexpensive method for the purification of DNA from lichens and their symbionts. The Lichenologist 27: 207-213.

Clerc, P. 1984a. Contribution à la révision de la systématique des usnées (Ascomycotina, Usnea) d'Europe I. Usnea florida (L.) Wigg. emend. Clerc. Cryptogamie, Bryologie et Lichenologie 5: 333-360.

Clerc, P. 1984b. Usnea wirthii, a new species of lichen from Europe and North Africa. Saussurea 15: 33-36.

Clerc, P. 1998. Species concepts in the genus Usnea (lichenized Ascomycetes). The Lichenologist 30: 321-340. 
Clerc, P. \& Roh, P.-D. 1979a. Effets du fluor sur la végétation lichénique corticole autour de la région de Martigny (VS). Bulletin de la Murithienne 96: 23-41.

Clerc, P. \& Roh, P.-D. 1979b. Les lichens, indicateurs biologique de la pollution atmosphérique, autour de la fabrique d'aluminium de Martigny (Valais, Suisse). Saussurea 11: 107-139.

Divakar, P. K., Crespo, A., Wedin, M., Leavitt, S. D, Hawksworth, D. L., Myllys, L., McCune, B., Randlane, T., Bjerke, J. W., Ohmura, Y., Schmitt, I., Boluda, C. G., Alors, D., Roca-Valiente, B., DelPrado, R., Ruibal, C., Buaruang, K., Núñez-Zapata, J., Amo de Paz, G., Rico, V. J., Molina, M. C., Elix, J. A., Esslinger, T. L., Tronstad, I. K. K., Lindgren, H., Ertz, D., Gueidan, C., Saag, L., Mark, K., Singh, K., Dal Grande, F., Parnmen, S., Beck, A., Benatti, M. N., Blanchon, D. J., Candan, M., Clerc, P., Goward, T., Grube, M., Hodkinson, B. P., Hur, J. S., Kantvilas, G., Kirika, P. M., Lendemer, J., Mattsson, J. E., Messuti, M. I., Miadlikowska, J., Nelsen, M., Ohlson, J. I., Pérez-Ortega, S., Saag, A., Sipman, H. J. M., Sohrabi, M., Thell, A., Thor, G., Truong, C., Yahr, R., Upreti, D. K., Cubas, P. \& Lumbsch, H. T. 2015. Evolution of complex symbiotic relationships in a morphologically derived family of lichen-forming fungi. New Phytologist 208: 1217-1226.

Döring, H., Clerc, P., Grube, M. \& Wedin, M. 2000. Mycobiont-specific PCR primers for the amplification of nuclear ITS and LSU rDNA from lichenized ascomycetes. The Lichenologist 32: 200-204.

Gadea, A., Charrier, M., Fanuel, M., Clerc, P., Daugan, C., Sauvager, A., Rogniaux, H., Boustie, J., Le Lamer, A.-C. \& Lohézic - Le Devehat, F. 2019. Overcoming deterrent metabolites by gaining essential nutrients: A lichen/snail case study. Phytochemistry 164: 86-93.

Gerlach, A., Toprak, Z., Naciri, Y., Caviró, E. A., Borges da Silveira, R. M. \& Clerc, P. 2018 (2019). New insights into the Usnea cornuta aggregate (Parmeliaceae, lichenized Ascomycota): Molecular analysis reveals high genetic diversity correlated with chemistry. Molecular Phylogenetics and Evolution 131: 125-137.

Habashi, C. \& Clerc, P. 2012. Inventaire des lichens de la Ville de Genève. Rapport du projet Aalborg. Conservatoire et Jardin botanique de la Ville de Genève.
Habashi, C. \& Clerc, P. 2013a. Plan d'action pour Phaeophyscia hirsuta (Mereschk.) Essl. Ville de Genève, Conservatoire et Jardin botanique de la Ville de Genève.

Habashi, C. \& Clerc, P. 2013b. Inventaire des lichens de la Ville de Genève. Rapport du projet «Nature en Ville». Conservatoire et Jardin botanique de la Ville de Genève.

Jung, P., Emrich, D., Briegel-Williams, L., Schermer, M., Weber, L., Baumann, K., Colesie, C., Clerc, P., Lehnert, L. W., Achilles, S., Bendix, J. \& Büdel, B. 2019. Ecophysiology and phylogeny of new terricolous and epiphytic chlorolichens in a fog oasis of the Atacama Desert. MycobiologyOpen 8(10): e894.

Messuti, M. I., Becker, U. \& Archer, A. W. 2007. New or interesting saxicolous Pertusaria species (Pertusariales: Pertusariaceae) from Zimbabwe. The Lichenologist 39: 227-230.

Motyka, J. 1936. Lichenum generis Usnea studium monographicum. Pars systematica (Vol. 1). Leopoldi (privately printed).

Motyka, J. 1938. Lichenum generis Usnea studium monographicum. Pars systematica (Vol. 2). Leopoldi (privately printed).

Nimis, P. L., Hafellner, J., Roux, C., Clerc, P., Mayrhofer, H., Martellos, S. \& Bilovitz, P. O. 2018. The lichens of the Alps - An annotated checklist. MycoKeys 31: 1-634.

Rojas, C., Morales, R. E., Calderón, I. \& Clerc, P. 2013. First records of myxomycetes for El Salvador. Mycosphere 4: 1042-1051.

Roux, C. 2020. Catalogue des lichens et champignons lichénicoles de France métropolitaine, 3e édition revue et augmentée (2020). Association française de lichénologie (AFL), Fontainebleau. 1-1341 pp.

Temu, S. G., Clerc, P., Tibell, L., Tibuhwa, D. D. \& Tibell, S. 2019. Phylogeny of the subgenus Eumitria in Tanzania. Mycology 10(4): 250-260.

Truong, C., Divakar, P. K., Yahr, R., Crespo, A. \& Clerc, P. 2013. Testing the use of ITS rDNA and protein-coding genes in the generic and species delimitation of the lichen genus Usnea (Parmeliaceae, Ascomycota). Molecular Phylogenetics and Evolution 68: 357-372.

Vust, M., Clerc, P., Habashi, C. \& Mermilliod, J.-C. 2015: Liste Rouge des lichens du canton de Genève. Hors-série 16: 1-159. 